\title{
ACERCA DE LA EXPERIENCIA DE ESCRIBIR COMO UNA MUJER
}

CONCHA GARCÍA

Poeta

RESUMEN: Este texto es una reflexión hecha en primera persona sobre la experiencia de la escritura desde la conciencia de una poeta. Se valoran las dudas, las fragilidades, las genealogías, las inscripciones culturales y el trayecto llevado a cabo en relación con esa posición.

PALABRAS CLAVE: poesía, mujer, Concha García.

\footnotetext{
${ }^{1}$ Esta contribución traslada la experiencia personal de una escritora y, dado que no presenta una investigación, no ha sido sometida al proceso de revisión por pares en doble ciego que ha superado el resto de artículos publicados en esta sección.
} 


\section{ON THE EXPERIENCE OF WRITING LIKE A WOMAN}

ABSTRACT: This text, a reflection in the first person on the experience of writing from the consciousness of a women poet, privileges the doubts, frailties, genealogies, cultural inscriptions and the journey effected during this process.

KEYWORDS: poetry, woman, Concha García.

T a experiencia que me produce releer mis propios poemas no deja de ser Luriosa. Hasta hace unos años sentía cierto prejuicio cuando repasaba alguno de mis poemarios y me detenía en un poema cualquiera. Sentía que aquello que estaba escrito formaba parte de un acontecimiento no necesariamente vivido, aunque fuese yo quien lo había escrito. Tampoco era del todo cierto que se tratara de una ficción porque algo mío, de mi historia, sin duda estaba reflejándose en el poema.

El prejuicio era generado por una falsa modestia que, en el fondo, me irritaba, pero no podía dejar de sentirlo. Releía y pensaba que era mucho mejor escoger cualquier otro poema alejado de mi autoría, de manera que yo misma me desautorizaba e impedía que los propios textos calasen en mí y me revelaran su significado profundo. ¿Por qué ese miedo? Releyéndome también descubrí significados que anticiparon experiencias posteriores, sentí que me conocía mejor a mí misma y que en mi conciencia había una trama de recuerdos, sensaciones, lecturas, frustraciones y deseos que no solo pertenecían a lo meramente personal.

Sabemos que todos estamos gobernados por nuestras historias personales y por las de las generaciones precedentes, y solemos remontar hasta el mito que atraviesa e irriga nuestro imaginario. Al leer mis poemas, la poderosa tempestad que me devolvía, desordenadamente, una historia personal filtrada por el eco de mis antecesoras, me reveló que hablaba en boca de un imaginario que se había instalado en mi voz poética asumiendo un papel todavía tímido, pero que emergía en el poema buscando un reconocimiento. Toda una genealogía femenina asomaba la cabeza en el texto.

Cuentan muchos poetas que la poesía nace al sonar en sus oídos una frase musical insistente, al principio inconcreta y luego precisa, pero todavía sin palabras. En algún instante, a través del fraseo musical, brotan de pronto esas palabras y comienzan a moverse los labios. Más musical que mental, el hilo poético se cruza con el musical y de ese fraseo adviene el canto. Las palabras son metáforas visuales que demuestran la dependencia de la escritura. Son acontecimientos. El pensamiento está integrado en el habla, el texto lo recoge.

En mi libro Acontecimiento hay un poema que titulé "Sin dolor". Escrito durante un momento en que esperaba a alguien en casa. Apareció de pronto. Yo estaba preparando la comida y sirviéndome una copa de vino blanco. Fue como si entre un acto y otro alguien me lo hubiese dictado. El texto surgía de las capas más profundas de mi psique:
Los primeros días
fueron un poco amargos, me refiero
a que la sensación se te ponía en la espalda
y se cumplía el designio.
Era un dolor como ajeno
un exceso de intimidad con ella,
un ir y venir de recuerdos que se tropezaban.
¿Cómo manifestarlo?
Si andabas apresurada, la calle no podía.
Si por el rabillo del ojo
entraban las esquinas adorables
hechas de cemento, claro, también
de vidrios, y qué escaparates.
Una hermosa lata de atún del sur
la sonrisa de la mujer
del dibujo, oh, qué momento,
mi madre poniendo la mesa, 
había sacado del cesto cien gramos

de todo el porvenir que le quedaba. (García, 2008: 17)

Sin duda el poema necesitaba ser dicho; tras él había una historia larga y repetida que formaba parte de mi historia, no sólo personal, sino que abarcaba un arco mucho más amplio relacionado con haber nacido mujer. La biología prefiguraba mi destino. Aunque sabemos que no hay una historia unívoca de la mujer, escribir y leer como una mujer es una opción política, es situarse en la parte más vulnerable de la historia.

Tres son las cuestiones que recorren este poema: la rememoración de una escena remota y desgajada de mi niñez (el inconsciente); la conciencia de que el sujeto es una mujer, y una entreverada sucesión de tiempos y espacios imaginados que me llevaron a una secuencia de mi infancia, cuando mi madre llegaba de la compra y sacaba del cesto los alimentos para ordenarlos en la nevera. Aquel acto formaba parte de un destino que se cumplía inexorablemente. Se trataba de ordenar la comida y organizar la alimentación de la familia. Su madre también había hecho lo mismo, y su abuela, y probablemente toda nuestra genealogía femenina. Ese exceso de recuerdos se intercalaba en la memoria, acentuando un designio que me correspondía, como he dicho, por haber nacido mujer.

El futuro iba a ser el resultado de haber existido en una experiencia que, por ser también mujer, me correspondería y a la que estaba destinada. Solo que yo, voluntariamente, al haber adquirido la conciencia de que no quería eso, iba a detenerlo y a cambiarlo.

En el juego con las imágenes del poema, la lata de atún, como la magdalena de Proust, me llevaba a la infancia mientras la miraba en un escaparate del barrio de Gracia de Barcelona. En el texto se concentraban experiencias imaginadas y reales, no en el sentido de la realidad lineal, ordenada, figurada, que selecciona los acontecimientos según un discurso aparentemente lógico. Me abría a la subjetividad y en ella yo podía sumergirme y encontrarme con trozos de espacios o minúsculas secuencias temporales que caprichosamente iban de aquí para allá intercalándose sin orden aparente. La poesía es también un juego de espacios y tiempos que siempre está a punto de estallar cuando se convierte en escritura.
En la escritura se asume el hábito del género de una forma compleja, que incluye el cuerpo y sus atavíos, y nos recuerda constantemente las relaciones de poder socioculturales. En la poesía que llegaba a mi generación no había más modelo que el de la tradición clásica. La diferencia tardaría en llegar.

Pero la imaginación, que ofrecía sus frenos represores, también proporcionaba una libertad estimulante: de repente te veías en un barco yendo hacia Santorini; o yendo al colegio tomada de la mano de tu madre, o en brazos de tu abuela, o en el campo, sintiendo la intensidad de la luz de la campiña cordobesa. Simultáneamente pensaba que tenía ganas de leer tal o cual libro, o que el domingo anterior no vino la persona que esperaba. Aquel vaivén de recuerdos e impresiones proporcionaba mi propio poema, una experiencia de primer orden que me devolvía a mí misma en un arco iluminado de pequeños instantes de inconsciencia.

La poesía sería el resultado de registrar todos esos átomos a medida que se posan sobre la mente y en el orden en que caen forman un dibujo que, por incoherente que pueda parecer, dibuja una trama de lo real. Lo real adquiría una mirada de mujer. Mi experiencia particular y exclusiva, gracias a una serie de crisis y conflictos que me relacionan muy directamente con otras mujeres de mi cultura, se convertía en la pátina de mis poemas.

Me he preguntado siempre en qué consiste escribir como una mujer. Una de las respuestas apela al sentido formal: se decía que la mujer cuando escribe poesía, en general, no ha sido tan esclava de las formas, pero esa afirmación no era cierta, muchas mujeres de la generación del 27 y del 60 escribían con estructuras tradicionales. Se trataba de algo que comenzaba más en el corazón de la escritura, en sus formas, en alimentar un cierto desorden. ${ }^{2}$

En un artículo publicado en Ínsula y titulado "Poco a poco he dejado de ser ella para ser una", cuestionaba aquel sujeto femenino creado

${ }^{2}$ Al respecto ha escrito Sharon K. Ugalde: "El desdén íntimo que siente por un sistema socio-psicológico patriarcal que prescribe un comportamiento femenino sofocante para la mujer" (Ugalde, 1995-1996: 230)

UNED. REI, 4 (2016), pp. 195-208

ISSN 2340-9029 
por el imaginario masculino. Decía: "Fijémonos que la mujer a la que alude el poema no está esperando que venga nadie, sino que se vaya, y que el gesto de poner un disco no significa otra cosa que el rito para exorcizar la sala de una presencia" (García, 1994). Escribir como una mujer era subjetivar a esa mujer en situaciones hasta entonces, al menos en nuestro país, insólitas: una mujer sola, que vive en un apartamento de un barrio obrero, va a trabajar y toma el autobús; le gusta caminar sin dirigirse a parte alguna. Es decir, todo aquello que podían hacer los hombres sin que fuese cuestionado. Con pocas mujeres poetas podía compartir aquella certeza, aunque el reconocimiento de un yo dividido fue un auto-descubrimiento que compartía con otras poetas españolas: Clara Janés, María Victoria Atencia, Juana Castro. Poco a poco se iría abriendo el campo literario simbólico y para dar cuenta de ello la poeta argentino-española Noni Benegas publicó en 1997 la antología Ellas tienen la palabra. ${ }^{3}$ El prólogo es un atinado estudio de la situación de las mujeres en aquellos momentos. Noni Benegas, apoyándose en las tesis de Pierre Bourdieu, explica el espacio de las relaciones de fuerza entre agentes o instituciones que tienen en común poseer el capital necesario para ocupar posiciones dominantes, por ejemplo, los campos de producción cultural.

Cuando conocí a María Xosé Queizán, Juana Castro, Noni Benegas, Olvido García Valdés, Ángeles Mora, Aurora Luque, María Cinta Montagut y Elsa López, entre otras poetas, más o menos a finales de los ochenta en adelante, comencé a sentirme menos sola. Compartir el campo simbólico, las aspiraciones que nos legitimaban como poetas sin la apostilla muchas veces peyorativa que nos relacionaba con lo femenino, no fue fácil. En 1997 se hizo necesario el primer Encuentro de Mujeres Poetas, que se celebró en Vigo. La idea surgió tomando un café en un bar del barrio gótico de Barcelona con María Xosé Queizán. Continuarían celebrándose durante siete años más en las ciudades de Córdoba, Málaga, Granada, San Sebastián, Barcelona, Lanzarote y Vitoria.

Pues bien, de aquellos Encuentros de Mujeres Poetas apenas hubo recepción en la prensa del momento. Sin duda a todas nos enriquecieron

${ }^{3}$ La edición es de Noni Benegas y Jesús Munárriz; el estudio preliminar de Noni Benegas. aquellos congresos anuales donde se compartían y debatían temas que habían sido hegemónicos en la Academia, como la construcción del canon o el exceso de visibilidad de los discursos masculinos en un país donde ninguna mujer había ganado premios como el Nacional o el de la Crítica. Se conseguiría, a pequeñas dosis, años después, gracias a nuestra insistencia para introducirnos en los lugares donde se produce el poder (presencia en antologías y jurados de premios literarios, sobre todo), planteando a la entonces ministra de cultura, Carmen Calvo, que fue muy receptiva, la paridad en los jurados literarios.

Me preguntaba qué cuestiones avisaban de que en un texto se hablaba de algo que rompía clichés o alteraba el orden del discurso patriarcal tan asumido que a veces no somos conscientes. Y me di cuenta de que cierto imaginario estaba tan petrificado en mí misma que ni siquiera me lo cuestionaba.

Sabemos que el imaginario social sobre la mujer y la feminidad se constituye a partir de la mirada y los fantasmas masculinos bajo la forma de ciertas figuras, como la mujer fatal, la mujer niña, la prostituta, o la virgen, convirtiéndonos en figuras extraídas de los textos.

Por cada paso que se ha dado, hemos derribado una hilera de libros canónicos que continúan representando el mundo desde un solo punto de vista. Un ejemplo de ellos es constatable en las antologías poéticas publicadas en España, sobre todo en los años ochenta y noventa. Resultaba curioso que en casi ninguna coincidiera la misma poeta. El resultado fue que los nombres de las pocas seleccionadas en algunas antologías se dispersasen y no se fijaran como el de los varones poetas, donde en casi todas se repiten sus nombres. Podemos echar mano de cualquier antología publicada en este país y se comprobará lo que afirmo.

Existe una experiencia común en casi todas las mujeres de mi generación y es la de haber nacido con un futuro ya predeterminado culturalmente, como he dicho anteriormente y que se reducía a dos cuestiones: casarse y tener hijos. Lo demás, la vida en su experiencia más gratificante que es el ejercicio de la libertad, se le negaba a la niña. Las cosas ahora no son así. Pero eran, y deben quedar escritas. Hay que denominar ve- 
razmente el mundo, como ha dicho Hilde Domin. Un poema de la poeta norteamericana Sharon Olds refleja muy acertadamente esto que digo:

Yo me remonto a mayo de 1937

Les veo, de pie, a las puertas rituales de sus universidades,

veo a mi padre paseándose

bajo el arco de piedra arenisca, color almagre,

los azulejos rojos centelleando

como torcidos platos de sangre detrás de su cabeza,

veo a mi madre con unos cuantos libros triviales a su lado,

de pie, donde la columna hecha de pequeños ladrillos,

con la puerta de hierro forjado todavía abierta detrás de ella,

sus puntas de espada negras en el aire de mayo;

están a punto de graduarse, a punto de casarse,

son chavales, son tontos, lo único que saben es

que son inocentes, nunca harán daño a nadie.

Quiero acercarme a ellos y decir, ¡alto!

No lo hagáis: ella no es la mujer

él no es el hombre que quieres, haréis cosas

que no podéis imaginar jamás haríais,

haréis cosas malas a niños,

sufriréis de manera inconcebible,

querréis morir. Quiero

acercarme a ellos allí a la luz solar de un mayo tardío y

decírselo,

la cara de ella, deseosa, bonita y vacía volviéndose a mí,

su pobre cuerpo hermoso, no tocado,

pero no lo hago. Quiero vivir.

Les recojo como esas muñequitas de papel,

hombre y mujer, les empujo uno contra el otro

por las caderas, como astillas de pedernal como para

encender una chispa de los dos, digo:

haced lo que vais a hacer, y yo lo contaré.

La autora se sitúa en una posición temporal en la que puede ver a sus padres antes de casarse y desea advertirles de que es un error lo que van a hacer. El poema está lleno de imágenes que simbolizan su futuro sombrío (azulejos centelleando, platitos de sangre, libros triviales, puerta de hierro forjado, puntas de espadas negras). Ella no puede hacer nada para detener el propio devenir de la existencia. Sabe que la escritura se encargará de relatarlo y de transformarlo. Sabe que esa es su obligación, que así nombrará "verazmente" el mundo. Al nombrarlo lo modificará.

Y así está ocurriendo. Las bodas ya no significan lo mismo que cuando yo era una adolescente, al menos me parece que quien se casa lo hace por propia elección. Aunque tampoco estoy segura de que el significado profundo de los compromisos adquiridos por presiones culturales se haya modificado demasiado, más bien no.

Como resultado de un cierto cambio de mentalidad, la manera de concebir el texto poético, sobre todo en la escritura de mujeres, ha dado un salto importante en cuestiones que reflejan la experiencia de la/una mujer desde una absoluta libertad, desacralizando los ritos que nos tenían asignados.

Otra de las cuestiones de la poesía escrita por mujeres en los últimos años es que se ha desprendido de unos clichés que nos identificaban a lo largo del siglo XX. Como sabemos, se había construido un imaginario donde era la mujer quien hablaba desde el cuerpo: amante, suicida, enferma, promiscua o lesbiana. En la poesía escrita por hombres no interesa tanto ni la sexualidad ni la vida personal.

Tenemos ejemplos sobrados de que se han convertido en un icono: Alfonsina Storni, Delmira Agustini, Ana Cristina César, Alejandra Pizarnik, Silvia Plath o Anne Sexton. Estas generaciones de poetas, poseídas por un alma atormentada (y es cierto, ha sido necesaria esa "aniquilación" para darse cuenta de que por ahí no era el camino) fue la antorcha que iluminaba el sendero de iniciación poética de muchas jóvenes, empezando por mí misma. Sus vidas ejercían una seducción fatal que estimulaba la creación. En el aire quedó eso, y eso es lo que respiré como lo canónico de las mujeres que escribían.

Quedó, en la poesía escrita por mujeres, una fatalidad con la que aún se nos identifica, reconozco que, en menor medida, pero no perdamos 
la pista de lo que el patriarcado todavía valida. Si la poeta muestra su dolor porque está enferma o cultiva el misticismo, va a ser mucho más fácil ser admitida en el canon occidental.

No nos engañemos, en la escritura de algunas mujeres encontramos las estructuras simbólicas que han contribuido a crear una concepción del género femenino conducente a la perpetuación de la inferioridad de las mujeres. No todas las mujeres son la mujer, eso ya lo dijo Simone de Beauvoir, porque, de lo contrario, nos situamos ante una falta de definición, en lo que yo llamo crear una expectativa.

Se espera "eso", no otra cosa: muerte y juego con el cuerpo. De eso mismo se ha nutrido el propio discurso de lo llamado femenino. Me interesan miradas más abiertas, menos sexualizadas, que rescaten de la invisibilidad y el silencio. Prefiero una poesía que ilumine nuestro papel en la historia y en la actualidad, desde muchas perspectivas: liviana y sutil, penetrante y múltiple. Que juegue e indague, que posibilite visiones de la realidad, que no reduzcan el trabajo literario de una mujer a su firma y sea común a hombres y mujeres. La poesía, al fin y al cabo, suscita aquello que nos parece familiar por haberlo conocido en una memoria remota.

Un poema de la poeta norteamericana Adrienne Rich expresa perfectamente y con ironía la semblanza de esa mujer que nos antecede:

Golpeando la cafetera en el fregadero

ella escucha a los ángeles increpantes, y mira hacia afuera

al confuso cielo más allá de los jardines rastrillados.

Hace solo una semana le dijeron: No seas paciente.

La próxima vez fue: Sé insaciable.

Luego: Sálvate a ti misma, no puedes salvar a otros.

A veces he dejado que el agua hirviente le queme el brazo

que un fósforo arda hasta quemarle la uña del pulgar,

o ha dejado su mano en el escape de la tetera

justo sobre el vapor caliente. Quizá sean ángeles,

puesto que a ella ya nada le hace daño, excepto

la arenisca matutina que se le mete en los ojos.
Me parece muy interesante la propuesta estética de este poema. Para empezar, comienza con la imagen de una mujer golpeando la cafetera (los utensilios del hogar representan el mundo femenino, pero ella lo subvierte). Continúa reflexionando mientras mira el cielo, más allá de los jardines rastrillados, ordenados. Los mandatos recibidos por su mera condición de mujer: insaciable, impaciente, salvarse a sí misma, se los cuestiona. Al mismo tiempo comienza el día simbolizado en el acto cotidiano de hacer un café. El último verso revela el contenido real del poema: un dolor del que no puede despegarse y que comienza al amanecer. ¿El dolor de existir?

Este poema me comunica lo que puedo sentir, como mujer, cuando nos cuestionamos lo cotidiano y trascendente simultáneamente en su dimensión de lo real. No hay nada que sobre ni que falte. Tampoco encontramos lirismo.

Otro ejemplo, en el que la mujer es relatada desde varios ángulos, nos lo da la poeta polaca Wislawa Szymborska. Lo que más me gusta de este poema es la seguridad con la que la autora perfila varios tipos de mujer, la contemplación de la misma desde distintas perspectivas y posibilidades. Es un poema que se ajusta correctamente a nuestra diversidad. No existe temática femenina única: la soledad, las cuestiones metafísicas, metapoéticas, eróticas, el amor y el desamor, son temas tratados por cualquier poeta. Tampoco la poesía escrita por mujeres tiene un tono concreto, hay poetas que escriben de una manera desafiante, otras testimonial, o carnavalesca, o con tonos amargos, o llenos de ironía. También hay mujeres que escriben sin conciencia feminista y rechazan esa palabra porque les parece que está cargada de negatividad:

\section{Retrato de mujer}

Tiene que ser para elegir.

Cambiar para que no cambie nada.

Es fácil, imposible, difícil, vale la pena intentarlo.

Tiene ojos, si hace falta, a veces grises, otras azules,

negros, alegres, llenos de lágrimas sin motivo.

Se acuesta con él como primera fila, la única en el mundo.

Le da cuatro hijos, no le da hijos, le da uno. 
Ingenua, pero da buenos consejos.

Débil, pero no puede con la carga.

No tiene nada en la cabeza, pero lo va a tener.

Lee a Jaspers y revistas femeninas.

No sabe para qué ese tornillo y construye un puente.

Jove, como de costumbre joven, constantemente joven.

Tiene en la mano un gorrión con el ala rota,

su propio dinero para un viaje largo y lejano,

un cuchillo, una compresa y un vaso de vodka.

a dónde va con tanta prisa , ¿no estará cansada?

Claro que no, sólo un poco, mucho, no importa.

O lo ama o está encaprichada.

En las buenas, en las malas y por el amor de Dios.

El poema funciona porque abre las posibilidades del significante. Estira y abarca una mirada amplia que focaliza en el hecho de ser mujer. Los versos sugieren y explican gracias a las paradojas que nos plantea la autora. La mujer está perfectamente perfilada y explicada, es un arco abierto de experiencias que cuestionan la autoridad androcéntrica, poco imaginativa cuando se ha tratado de construir, como he dicho antes, el imaginario femenino.

Cuando alguien lee poesía, la mayoría de las veces, no se cuestiona todos estos asuntos que estoy exponiendo. Sé que el poema funciona o no funciona y que raramente puede explicarse sin tener en cuenta las dosis de irracionalidad que encierra. En realidad, me pregunto ¿para qué sirve un poema? Decía Freud en su ensayo El malestar en la cultura: "No podemos por menos de suspirar desconsolados al advertir cómo a ciertos hombres les es dado hacer surgir del torbellino de sus propios sentimientos, sin esfuerzo alguno, los más profundos conocimientos”. Donde no llegaba él mismo, llegaba el poeta.

Desde luego la poesía ayuda a que la subjetividad y la conciencia cambien de tonos. El poema, cuando nos llega al alma, es que funciona, y nos devuelve mucho de nosotras mismas, de nuestras certezas y dudas, de nuestra condición efímera, de nuestro concepto de la belleza. Nos recono- cemos en él porque es un hecho de lenguaje, no se necesitan conceptos ni largas explicaciones para que el poema llegue.

Lamentablemente, como lectoras hemos aprendido a desconfiar de lo que se muestra como verdad universal y muchas poetas revisan los mitos, la historia, la cultura, el erotismo, la relación con el otro o la otra, justamente para completar las malversadas imágenes literarias de las mujeres. Ejemplo de ello - y nombro a las poetas en las que reconozco el trabajo de re-nombrar el mito- es la poesía de Juana Castro, Ana Rossetti, Aurora Luque o María Antonia Ortega.

Como sostiene Hélène Cixous, en literatura, la feminidad se puede distinguir en la primacía de la voz: voz y escritura se funden en uno. La mujer que habla es enteramente su voz: "Materializa físicamente lo que piensa, lo que indica con su cuerpo". En otras palabras, la mujer está total y físicamente en su voz, y su obra escrita no es más que una extensión del acto de hablar reflejo de su propia identidad. También hay otras opiniones, como la de Rosi Braidotti - es la que más me interesa-, que elabora la teoría de sujetos nómades que tratan de escapar del dualismo tradicional, y que bebe de las fuentes rizomáticas de Gilles Deleuze y Felix Guattari. O las tesis de Kristeva y de Cixous, que fundan un imaginario en el que el mito de Edipo pierde el protagonismo que le dio Freud para explicar la "novela familiar" y recuperar la voz pre-edípica femenina.

La renuncia es otro de los grandes temas relacionados con la mujer; de ahí la tendencia a identificar universalmente la poesía con el sufrimiento, y más la poesía escrita por mujeres en general. Existen excepciones, claro, pero pocas. La alegría de vivir ha sido transmitida por pocas poetas. Pensemos. Hemos tenido que decir muchas cosas, hemos tenido que morir muchas veces, hemos tenido que maltratarnos, que suicidarnos, que entrar de puntillas a los salones literarios, hemos sido ignoradas y utilizadas, hemos sido silenciadas, también deseadas, pero nos han imposibilitado el acceso a la cultura. No estoy hablando de hace siglos.

Hemos sido representadas bajo una ausencia absoluta de nuestra propia perspectiva de mujeres en los grandes relatos culturales. Como escribió Virginia Wolf en su Habitación propia (1929): "Durante todos estos 
siglos, las mujeres han servido de espejos dotados del mágico y delicioso poder de reflejar la figura del hombre al doble de su tamaño natural".

\section{Referencias bibliográficas}

Benegas, Noni y Jesús Munárriz, eds. (1977), Ellas tienen la palabra. Dos décadas de poesía española, Madrid: Hiperión.

García, Concha (1994), "Poco a poco he dejado de ser ella para ser una", Ínsula, 565, pp. 22-23.

- (2008), Acontecimiento, Barcelona: Tusquets.

Ugalde, Sharon K. (1995-1996), "La poesía subversiva de Concha García", Letras peninsulares, 8/2-3, pp. 229-240. 